\title{
Actual Approaches in Prevention of Early Childhood Caries
}

AT Mutluay ${ }^{1}$, M Mutluay $^{2}$

\begin{abstract}
Objective: The studies which based on preventive programs presented that promotion of the mother's oral health status and diet habits provide a simple, long-term and very important protection on the infant caries. Also, it is reported that oral health educations, preventive applications and dietery recommendations can prevent bacterial transmission from mothers to infants during the infectivity window. The aim of this paper is to explore actual preventive approaches in eliminating the occurrence of dental caries in early primary dentition period.

Methods: A comprehensive literature search of the basic and actual published studies in PubMed/MEDLINE regarding the efficacy of preventive methods and dental treatments aiming to prevent of early childhood caries was performed.

Conclusion: Preventive interventions in mothers may cause decline in the future caries experience of infants. Dental treatment of mothers with high numbers of MS by dietary and antimicrobial measures could reduce the risk of spreading cariogenic microorganisms to their infants and thus reduces the caries risk in the children.
\end{abstract}

Keywords: Dental caries, early childhood caries, mutans streptococci, primary prevention

From: ${ }^{1}$ Department of Restorative Dentistry, Faculty of Dentistry, Kirikkale University, Kirikkale, Turkey. ${ }^{2}$ Department of Pediatric Dentistry, Faculty of Dentistry, Kirikkale University, Kirikkale, Turkey.

Correspondence: Dr M Mutluay, Department of Pediatric Dentistry, Faculty of Dentistry, Kirikkale University, Kirikkale, Turkey. E-mail: mervkrts@hotmail.com 


\section{INTRODUCTION}

Dental caries is an infectious disease that is caused by demineralization of inorganic components of the dental hard tissues due to bacterial acids (1). Despite general advances in preventing therapies of dental caries, today it is still a public health problem. The disease is more widespread in the developed countries due to greater simple sugar consumption (2).

As dental caries results from interactions between teeth and acids produced by acidogenic bacteria (Mutans streptococci and lactobacillus species), there is a close relationship between dental caries and cariogenic bacteria (3). The bacterial acids cause $\mathrm{pH}$ decrease resulting in demineralisation of susceptible tooth tissue $(4,5)$. Pathological factors which include the presence of pathogenic bacteria, reduced salivary secretion, and increased frequency of fermentable carbohydrates consumption advance this process. On the other hand, protective factors which include protective salivary components, increased salivary flow, and fluoride or intake of other reminalization/antibacterial agents can balance, prevent, or reverse dental caries (6).

Tooth decay is among the most expensive infections experienced during life (1). The economic burden of tooth decay, which can progress into pulp infections if remains untreated, is expressed in million dollars (7). Nowadays, there has been a transition in management of dental caries from operative methods to a preservative approach (8). This article reviews knowledge of early childhood caries and preventive strategies of this multifactorial disease before any treatment requirement.

\section{Pathology of dental caries}

Tooth decay is defined as a micro-level mineral loss on the tooth surface by acid production of acidic and acidogenic bacteria in the presence of increased fermented carbohydrate intake (9). It is emphasized that there is a significant relationship between the amount of the bacteria named Mutans streptococci, in particular Streptococcus mutans (S. Mutans) and incidence of 
tooth decay $(9,10)$. As a result of its ability to colonize at the tooth surface, $S$. Mutans can cause a marked reduction in oral $\mathrm{pH}$ in the presence of a sugar substrate and thus induce demineralization of dental hard tissues (11). Lactobacilli associated with dentin caries and progress of caries lesion. Acid production of these cariogenic bacteries led to demineralization of dental tissues and cavity formation (9).

The dental plaque is described as a complex biofilm layer which is attached to the tooth surface and formed by microorganisms embedded in microbial originated extracellular matrix polymers (12). Susceptible tooth, caries-causing bacteria present in the dental plaque which formed on tooth surface and acidogenic diet main causative factors are dental caries. Early plaque accumulation in primary and mixed dentition is accepted a sign of caries risk in children (9).

\section{Transmission of the disease}

The primary way to prevent tooth decay which is an infectious disease is to prevent the spread of the causative agent in the community. Mothers are considered to be the primary source of transmission of caries infection to new-borns and infants can be infected between 1.5 and 3 years of age (13). Early childhood caries (ECC) is defined as an infectious and transmissible disease. ECC is strongly associated and caused by the bacteria $S$. Mutans and it is known that infants receive $S$. Mutans from their mother or other family members (14).

The primary way to prevent ECC is to inhibit transmission of the dominant bacteria (14). S. Mutans colonization in new-born begins with the eruption of primary teeth and reaches the highest levels in months 19-31 in line with the increased number of erupted teeth. This period is also defined as "infectivity window", and new-borns are at greater risk of becoming infected from their mothers and caregivers $(9,13,14)$. Poor maternal oral health in pregnancy and postpartum period can contribute caries development in new-borns through infectious, genetic, social and behavioural factors (15). It is reported that $S$. Mutans binds to 
human salivary components and cannot maintain its vitality outside the oral cavity (16). Thus, the most important factor in spread of $S$. Mutans infection is saliva transfer from infected individuals $(9,13,14)$. Previous studies have reported that caries in mothers can transfer caries-causing oral bacteria to her child (vertical way) (17-19). Also, the bacteria can be transmitted if the siblings use same pacifier or utensils (horizontal way) (20). It has been reported that the transmission of MS to infants occurs later and that the acquisition of bacterial genotypes is prevented or delayed through parental education of preventive oral health practices and dietary suggestions (21-23).

\section{Mother's role in management of dental caries}

The individual's future oral health is greatly influenced by early childhood hygiene procedures and habits. It is essential to improve oral hygiene practice of mothers and caregivers via preventive programs and treatment of their primer caries lesions (24). Maternal S. Mutans and Lactobacilli levels detected using the current diagnostic tests indicate the risks of maternal transmission and put caries preventive measures into practice for infants $(9,10,19)$. Motherchild caries prevention programs are suggested as a very modern approach to inhibit bacteria transmission to infants and prevention of development of early childhood caries, especially in the areas of low socio-economic levels with limited access to dentists (25). The necessity of the mother's oral health programs which aim to reduce the number of caries in children has been proven at long-term studies $(23,24,26)$.

The increasing awareness of mother about oral health facts and practices of the later generations are essentials of primary prevention concept. Furthermore, the earlier the preventive programs are applied in the patient, the less likely dental plaque originated diseases will develop (25). Breastfeeding or giving bottle at bedtime creates a suitable environment for the rapid growth of bacteria. Decreased release of saliva during night-time facilitates dissolution of dental hard tissues by acidogenic bacteria products (27). For this 
reason, mothers should stop giving bottle during sleeping and be instructed to clean the primary teeth before putting the baby to sleep (28). The frequent intake of high-sugar foods and snacking habits has also been associated with early childhood caries in infants (28). Mothers should be given oral health care information during the ante- or postnatal periods and have active participation in oral preventive programs $(29,30)$. Also, the patients should believe that the program is essential for prevention of the oral diseases (23).

Nowak and Casamassimo (31) reported that preventive applications implemented with family physicians can increase the number of non-carious individuals in the community and may be useful in parents' oral health education. Pierce et al. (32) reported that after 2 hours of training, the paediatric primary care providers in their study achieved an adequate level of accuracy in identifying children with cavitated carious lesions and they were able to identify the children who need to see a dental treatment. Kagihara et al. (33) emphasized that preventive programs with primary health care provider-delivered guidance are highly effective in preventing ECC. Multiple studies have also documented that reduced amount of MS salivary levels in mothers have led to reduced MS colonization or caries activity in their infants (Table 1).

\section{Determination caries risk status and oral hygiene procedures}

Caries risk may be defined as the probability that a specific number of new lesions will develop and/or a specific number of existing lesions will progress over a specified period of time. Determination of caries risk of society ensures early detection and diagnosis of caries lesions and periodontal diseases (38). The health authorities use a variety of index systems to determine the public oral health status. DMFT (Number of Decayed, Missing, Filling tooth) and DMFs (Number of Decayed, Missing, Filling tooth surface) which are used based on the proposal of World Health Organization (WHO) describe the tooth decay prevalence of populations. DMFT and DMFS stand for the most powerful predictor of all for caries 
increment associated with high-risk patients and used to make a prediction about future caries risk of patients (38).

It is well documented that caries protection programs among high-risk individuals can prevent early colonization of $S$. Mutans, mainly during the first 2.5 years of age $(29,35,37)$. Mother or caregiver has active caries, low salivary flow, high microbial count, defective restorations, special health care need or low socioeconomic status need caries progression and prevention program and regular monitoring (39). All these markers are important to determine precautions and minimal treatment methods about caries lesions and periodontal diseases in extremely high-risk mothers (39). Oral health education, dietary recommendations, treatment of caries lesions and periodontal tissues are basic methods used in these programs for suppression of bacterial growth in the oral cavity. Caries management also requires an antibacterial agent in combination with fluoride (25).

Dental plaque is a layer which is composed of salivary proteins and bacteria. It is the main cause of the periodontal diseases and tooth decay (12). High amount of plaque with poor oral hygiene means results in an elevated level of disease-causing bacteria adhered to the tooth surface and this plaque becomes more cariogenic in a synergistic way when nutritional sugar is added because this combination produces acids that begin the tooth demineralization $(1,7,12)$. The most effective way of removing of dental plaque and control the plaque bacteria is regular toothbrushing, using dental floss, and mouthwashing habits (25). Toothbrushing with a fluoridated toothpaste is able to remove plaque sufficiently and is effective in reducing caries incidence (40). Also, flossing will remove interproximal plaque and control dental caries and periodontal diseases (41). Individuals who have good oral hygiene have a lower incidence of caries and systemic diseases (42).

It has been shown that regular toothbrushing with fluoride containing toothpaste, using dental floss and mouthwash, chewing xylitol gum, and treatment of dental caries and 
periodontal diseases by dentists give rise to a lowered probability of transmitting maternal $S$. Mutans to their infants (43). According to available literature, mothers whose saliva levels of S. Mutans is at least $10^{5}$ per $\mathrm{ml}$, the probability of colonization is higher than others (44). The reduction in maternal $S$. Mutans levels minimizes the caries incidence, and the probability of transmission of S. Mutans from mothers to their infants (45).

\section{CONCLUSION}

Dental caries requires active leadership and promotion by the dental professionals. In case preventive programs are started before pregnancy, plaque-originated oral diseases can be prevented. Preventive techniques can effectively control cariogenic bacteria and other pathogens, and can inhibit their transmission. This not only means prevention of tooth caries and periodontal diseases but also provides economic benefits. The mother should be aware of the fact that the oral hygiene and feeding habits she has developed during pregnancy and postpartum period will directly affect the oral health of the infant. They should also be reminded that sleeping with the bottle or breastfeeding at night poses a significant risk for ECC. 


\section{REFERENCES}

1. Marsh PD. Role of the oral microflora in health. Microb Ecol Health Dis 2000; 12: $130-7$.

2. Tinanoff N, Reisiine S. Update on early childhood caries since the surgeon general's report. Acad Pediatr 2009; 9: 396-403.

3. Balakrishnan M, Simmonds RS, Tagg JR. Dental caries is a preventable infectious disease. Aust Dent J 2000; 45: 235-45.

4. Featherstone JD. The caries balance: contributing factors and early detection. J Calif Dent Assoc 2003; 31: 129-33.

5. Caufield PW, Griffen AL. Dental caries: an infectious and transmissible disease. Pediatr Clin North Am 2000; 47: 1001-19.

6. Featherstone JDB. Prevention and reversal of dental caries: role of low level fluoride. Community Dent Oral Epidemiol 1999; 27: 31-40.

7. Siqueira JF. Pulpal infections, including caries. In: Hargreaves KM, Goodis HE, Tay FR, eds. Seltzer and Bender's Dental Pulp. $2^{\text {nd }}$ ed, Chicago: Quintessence, 2012.

8. Selwitz RH, Ismail AI, Pitts NB. Dental caries.Lancet. 2007; 369: 51-9.

9. Caufield PW, Cutter GR, Dasanayake AP. Initial acquisition of mutans streptococci by infants: evidence for a discrete window of infectivity. J Dent Res 1993; 72: 37-45.

10. Lee C, Tinanoff N, Minah G, Romberg E. Effect of Mutans streptococcal colonization on plaque formation and regrowth in young children $-\mathrm{A}$ brief communication. $\mathrm{J}$ Public Health Dent 2008; 68: 57-60.

11. Kleinberg I. A mixed-bacteria ecological approach to understanding the role of the oral bactera in dental caries causation: An alternative to Streptococcus mutans and the specific-plaque hypothesis. Crit Rev Biol Med 2002; 13: 108-25. 
12. Rickard AH, Gilbert P, High NJ, Kolenbrander PE, Handley PS. Bacterial coaggregation: an integral process in the development of multi-species biofilms. Trends Microbiol 2003; 11: 94-100.

13. Dasanayake AP, Caufield PW. Prevalence of dental caries in Sri Lankan aboriginal Veddha children. Int Dent J 2002; 52: 438-44.

14. Carletto Korber FP, Cornejo LS, Gimenez MG. Early acquisition of Streptococcus mutans for children. Acta Odontol Latinoam 2005; 18: 69-74.

15. Shearer DM, Thomson WM. Intergenerational continuity in oral health: a review. Community Dent Oral Epidemiol 2010; 38: 479-86.

16. Nakai M, Okahashi N, Ohta H, Koga T. Saliva-binding region of Streptococcus mutans surface protein antigen. Infection 1993; 61: 4344-9.

17. Li Y, Wang W, Caufield PW. The fidelity of mutans streptococci transmission and caries status correlate with breast-feeding experience among Chinese families. Caries Res 2000; 34: 123-32.

18. Meyer K, Geurtsen W, Günay H. An early oral health care program starting during pregnancy. Clin Oral Investig 2010; 14: 257-64.

19. Kohler B, Andréen I. Mutans streptococci and caries prevalence in children after early maternal caries prevention: a follow-up at 19 years of age. Caries Res 2012; 46: 474 80.

20. Wan AK, Seow WK, Purdie DM, Bird PS, Walsh LJ, Tudehope DI. Oral colonization of Streptococcus mutans in six-month-old predentate infants. J Dent Res 2001; 80: $2060-5$.

21. Söderlıng E, Isokangas P, Pınıhäkkınen K, Tenovuo J, Alanen P. Influence of maternal xylitol consumption on mother-child transmission of mutans streptococci: 6year follow-up. Caries Res 2001; 35: 173-7. 
22. Lindquist B, Emilson CG. Colonization of Streptococcus mutans and Streptococcus sobrinus genotypes and caries development in children to mothers harboring both species. Caries Res 2004; 38: 95-103.

23. Douglass JM, Li Y, Tinanoff N. Association of mutans streptococci between caregivers and their children. Pediatr Dent 2008; 30: 375-87.

24. Zanata RL, Navarro MF, Pereira JC, Franco EB, Lauris JR, Barbosa SH. Effect of caries preventive measures directed to expectant mothers on caries experience in their children. Braz Dent J 2003; 14: 75-81.

25. Harris NO. Introduction to primary preventive dentistry. In: Harris NO, Garcia-Godoy F, eds. Primary Preventive Dentistry. $6^{\text {th }}$ ed, New Jersey: Pearson Education, 2004.

26. Güler E, Köprülü H. Preventive measures to reduce the transfer of Streptococcus mutans from pregnant women to their babies. J Dent Sci 2011; 6: 14-8.

27. Petersson GH. Assessing caries risk. The cariogram model. In: Wilson NHF, eds. Minimally Invasive Dentistry: The Management of Caries. London: Quintessence, 2007.

28. Mohebbi SZ, Virtanen JI, Murtomaa H, Vahid-Golpayegani M, Vehkalahti MM. Mothers as facilitators of oral hygiene in early childhood. Int J Paediatr Dent 2008; 18: $48-55$.

29. Gomez SS, Weber AA, Emilson CG. A prospective study of a caries prevention program in pregnant women and their children five and six years of age. ASDC J Dent Child 2001; 68: 191-5.

30. Chan SCL, Tsai JSJ, King NM. Feeding and oral hygiene habits of preschool children in Hong Kong and their caregivers' dental knowledge and attitudes. Int J Paediatr Dent 2002; 12: 322-31. 
31. Nowak AJ, Casamassimo PS. Using anticipatory guidance to provide early dental intervention. J Am Dent Assoc 1995; 126: 1156-63.

32. Pierce KM, Rozier RG, Vann WF. Accuracy of pediatric primary care providers' screening and referral for early childhood caries. Pediatrics 2002; 109: E82-2.

33. Kagihara LE, Niederhauser VP, Stark M. Assessment, management, and prevention of early childhood caries. J Am Acad Nurse Pract 2009; 21: 1-10.

34. Brambilla E, Felloni A, Gagliano M, Malerba A, Garcia-Godoy F, Strohmenger L. Caries prevention during pregnancy: results of a 30-month study. J Am Dent Assoc 1998; 129: 871-7.

35. Gomez SS, Weber AA. Effectiveness of a caries preventive program in pregnant women and new mothers on their offspring. Int J Paediatr Dent, 2001; 11: 117-22.

36. Dasanayake AP, Wiener HW, Li Y, Vermund SH, Caufield PW. Lack of effect of chlorhexidine varnish on Streptococcus mutans transmission and caries in mothers and children. Caries Res, 2002; 36: 288-93.

37. Thorild I, Lindau B, Twetman S. Caries in 4-year-old children after maternal chewing of gums containing combinations of xylitol, sorbitol, chlorhexidine and fluoride. Eur Arch Paediatr Dent 2006; 7: 241-5.

38. Anusavice J. Caries risk assessment. Operative Dentistry, 2001; 26: 19-26.

39. American Academy of Pediatric Dentistry: Guideline on caries-risk assessment and management for infants, children, and adolescents. Pediatr Dent 2013; 35: E157-64.

40. Andlaw RJ: Oral hygiene and dental caries - a review. Int Dent J 1978; 28: 1-6.

41. Hujoel PP, Cunha-Cruz J, Banting DW, Loesche WJ. Dental flossing and interproximal caries: a systematic review. J Dent Res 2006; 85: 298-305.

42. Li X, Kolltveit KM, Tronstad L, Olsen I. Systemic diseases caused by oral infection. Clin Microbiol Rev 2000; 13: 547-58. 
43. Soderling E, Isokangas P, Pienih AK, Tenovuo J. Influence of maternal xylitol consumption on acquisition of mutans streptococci by infants. J Dent Res 2000; 79: 882-7.

44. Berkowitz RJ: Causes, treatment and prevention of early childhood caries. a microbiologic perspective. J Can Dent Assoc 2003; 69: 304-7.

45. Emilson CG. Potential efficacy of chlorhexidine against mutans streptococci and human dental caries. J Den Res 1994; 73: 682-91.

46. Kohler B, Andréen I. Influence of caries-preventive measures in mothers on cariogenic bacteria and caries experience in their children. Arch Oral Biol 1994; 39: 907-11. 
Table: Studies that reported $S$ mutans transmission mother to her child

\begin{tabular}{|c|c|c|c|c|}
\hline Author, year & $\begin{array}{l}\text { Mother-and- } \\
\text { child pairs }\end{array}$ & $\begin{array}{l}\text { Preventive measures } \\
\text { to reduce the transfer }\end{array}$ & $\begin{array}{l}\text { Follow-up } \\
\text { period }\end{array}$ & Clinical relevance \\
\hline $\begin{array}{l}\text { Brambilla et } \\
\text { al. } 1998\end{array}$ & $\begin{array}{l}\text { Pregnant women } \\
\text { and their babies } \\
(n=65)\end{array}$ & $\begin{array}{l}0,05 \% \mathrm{NaF} \text { and } 0,12 \% \\
\text { CHX mouthwash }\end{array}$ & 30 months & $\begin{array}{l}\text { Treatment significantly reduced } \\
\text { salivary } S \text {. Mutans levels in } \\
\text { mothers and delayed the } \\
\text { colonization of bacteria. }\end{array}$ \\
\hline $\begin{array}{l}\text { Gomez and } \\
\text { Weber } 2001\end{array}$ & $\begin{array}{l}\text { Pregnant women } \\
\text { and new mothers } \\
\text { on their offspring } \\
(\mathrm{n}=360)\end{array}$ & $\begin{array}{l}\text { Fluoride varnish and } \\
\text { restoration of caries }\end{array}$ & 3 years & $\begin{array}{l}\text { The preventive dental program } \\
\text { was effective in inhibiting caries } \\
\text { in pre-school children }\end{array}$ \\
\hline $\begin{array}{l}\text { Gomez et al. } \\
2001\end{array}$ & $\begin{array}{l}\text { Pregnant women } \\
\text { and their babies } \\
(n=137)\end{array}$ & $\begin{array}{l}\text { Fluoride varnish and } \\
\text { restoration of caries }\end{array}$ & $\begin{array}{l}5 \text { and } 6 \\
\text { years }\end{array}$ & $\begin{array}{l}\text { The preventive dental program } \\
\text { was effective for a long-term } \\
\text { reduction of dental caries }\end{array}$ \\
\hline $\begin{array}{l}\text { Dasanayake et } \\
\text { al. } 2002\end{array}$ & $\begin{array}{l}\text { Mothers who } \\
\text { have } 6 \text { months old } \\
\text { infants }(n=75)\end{array}$ & $\begin{array}{l}10 \% \quad \text { Chlorhexidine } \\
\text { varnish }\end{array}$ & 42 months & $\begin{array}{l}\text { This intervention did not } \\
\text { significantly alter the } S \text {. Mutans } \\
\text { colonization in children or the } \\
\text { caries increment }\end{array}$ \\
\hline $\begin{array}{l}\text { Thorild et al. } \\
2006\end{array}$ & $\begin{array}{l}\text { Women } \quad \text { with } \\
\text { new-born babies } \\
(\mathrm{n}=173)\end{array}$ & $\begin{array}{lr}\text { Chewing } & \text { gums } \\
\text { containing } & \\
\text { combinations } & \text { of } \\
\text { xylitol, } & \text { sorbitol, } \\
\text { chlorhexidine } & \text { and } \\
\text { fluoride } & \end{array}$ & 4 years & $\begin{array}{l}\text { Less caries was observed in } \\
\text { children of mothers who chewed } \\
\text { gums with xylitol. }\end{array}$ \\
\hline $\begin{array}{l}\text { Güler and } \\
\text { Köprülü, } 2011\end{array}$ & $\begin{array}{l}\text { Pregnant women } \\
\text { and their babies } \\
(n=60)\end{array}$ & $\begin{array}{l}\text { Fluoride varnish and } \\
\text { restoration of active } \\
\text { caries }\end{array}$ & 24 months & $\begin{array}{l}\text { The preventive program applied } \\
\text { to the pregnant women reduced } \\
\text { both the amount of plaque and } S \text {. } \\
\text { Mutans colonization. }\end{array}$ \\
\hline $\begin{array}{l}\text { Köhler and } \\
\text { Andreen } 2012\end{array}$ & $\begin{array}{l}\text { Mothers who } \\
\text { have } 6 \text { months old } \\
\text { infants }(n=66)\end{array}$ & $\begin{array}{l}\text { fluoride treatment and } \\
\text { the treatment of open } \\
\text { carious lesions. }\end{array}$ & 19 years & $\begin{array}{l}\text { Early-colonised children, } \\
\text { irrespective of group identity, had } \\
\text { higher salivary MS levels and } \\
\text { DFS than later MS-colonised } \\
\text { children }\end{array}$ \\
\hline
\end{tabular}

